Jurnal Kejuruteraan SI 1(1) 2018: 31-36

http://dx.doi.org/10.17576/jkukm-2018-si1(1)-05

\title{
Morphological Studies on the Agglomeration of FeCo Supported Nitrogen-doped Reduced Graphene Oxide Catalyst Prepared at Varying Annealing Temperature
} \author{
yang Disediakan pada Suhu Sepuh Lindap Berbeza) \\ Shuaiba Samad, Yusra Nadzirah Yusoff, Kee Shyuan Loh*, Wai Yin Wong \\ Fuel Cell Institute \\ Universiti Kebangsaan Malaysia, Malaysia
}

(Kajian Morfologi Terhadap Aglomerasi Mangkin FeCo Disokong Nitrogen-didopkan dengan Grafin Oksida Terturun

ABSTRACT

\begin{abstract}
One of the barriers to the large-scale commercialization of proton exchange membrane fuel cells (PEMFCS) is the high-priced of noble metals such as platinum (Pt). Therefore, in this paper, bimetallic electrocatalyst FeCo supported nitrogen-doped reduced graphene oxide (FeCo-NG) for oxygen reduction reaction (ORR) is proposed and has been successfully prepared through annealing of a mixture containing Fe, Co salts, dicyandiamide (DCDA) and graphene oxide (GO). The starting material GO appeared to be in multilayer sheets through scanning electron microscopy (SEM) and transmission electron microscopy (TEM) analysis. Due to the high annealing temperature and the absence of the surfactant, agglomeration of FeCo nanoparticles was observed from the morphology analysis. The macrostructure size of the metals particles was observed to be increased over temperature. As the temperature increases, the agglomeration gets more intense because of the increased of van der Waals cohesive forces between the nanoparticles. In addition, the weak electrostatic interaction between the metal cations with the nitrogen and the GO sheets could also be the cause of the agglomeration. The weak electrostatic interaction caused the nanoparticles ( $\mathrm{Fe}$ and $\mathrm{Co}$ ) not attracted onto the GO sheets thus inhibit the reduction of FeCo and GO to occur in situ simultaneously. It is believed that the agglomeration of the electrocatalyst $\mathrm{FeCo-NG}$ could results to poor electrocatalytic activity of PEMFC.
\end{abstract}

Keywords: Agglomeration; Iron cobalt; Catalyst; Surfactant; Proton exchange membrane fuel cell

ABSTRAK

Salah satu halangan untuk pengkomersialan sel fuel membran pertukaran proton (PEMFC) berskala besar adalah kos logam adi platinum (Pt) yang terlalu tinggi. Dalam kajian ini, elektromangkin dwilogam FeCo disokong nitrogen-didopkan dengan grafin oksida terturun ( $\mathrm{FeCo}-\mathrm{NG}$ ) untuk tindak balas penurunan oksigen diusul dan berjaya disediakan melalui kaedah penyepuhlindapan dengan campuran garam $\mathrm{Fe}$, Co, disiandiamida (DCDA) dan grafin oksida (GO). Analisis mikroskopi elektron pengimbasan (SEM) dan mikroskopi elektron transmisi (TEM) menunjukkan grafin oksida adalah dalam keadaan lembaran berbilang lapisan. Selain itu, terdapat aglomerasi zarah nano yang dapat dilihat melalui pencirian morfologi. Punca aglomerasi tersebut dipercayai disebabkan oleh suhu penyepuhlindapan yang tinggi dan ketiadaan surfaktan semasa proses sintesis elektromangkin dwilogam FeCo. Pertambahan saiz makrostruktur zarah logam juga dapat dilihat dengan jelas apabila suhu meningkat. Apabila suhu meningkat, aglomerasi semakin jelas kelihatan kerana daya lekitan van der Waals antara zarah nano bertambah. Aglomerasi tersebut juga berkemungkinan disebabkan oleh daya interaksi elektrostatik yang lemah di antara logam kation dengan nitrogen dan lapisan GO. Daya interaksi elektrostatik yang lemah itu juga menyebabkan zarah nano (Fe dan Co) tidak mampu membentuk ikatan dengan lapisan grafin oksida dan seterusnya menghalang proses penurunan logam FeCo dan grafin oksida untuk berlaku secara in situ. Ia adalah dipercayai bahawa aglomerasi elektromangkin $\mathrm{FeCo}-\mathrm{NG}$ boleh menyebabkan aktiviti elektromangkin yang rendah.

Kata kunci: Aglomerasi; Ferum kobalt; Mangkin; Surfaktan; Sel fuel membran pertukaran proton

\section{INTRODUCTION}

Proton exchange membrane fuel cell (PEMFC) generally consists of three major components: an anode (commonly platinum or platinum-based catalyst), a thin, solid polymeric sheet (acts as electrolyte) and a cathode (platinum-catalysed) (Kamaruddin et al. 2007). Pt-based electrocatalysts are obtainable at a very high price. For only $10 \mathrm{~g}$ of $\mathrm{Pt}$, it costs around 1000-2000 US\$ and based on a few reports, Pt- based electrocatalyst is slowly facing diminishing catalytic activity (Samad et al. 2018). These drawbacks are among the major challenges for the commercialization of PEMFC. Thus, recent research focuses more on exploring and developing other alternative electrocatalyst that are way cheaper and exhibit excellent electrocatalytic activity. Non-noble metal electrocatalysts supported with carbon materials (with the lower cost, higher catalytic activity and excellent durability) have been actively pursued over the past few years (Bashyam 
\& Zelenay 2006; Gong et al. 2009; Zheng et al. 2012). Carbon materials as support have gained great interest with various modifications in order to prepare support with the higher specific surface area thus enhance the fuel cell performance. The most popular approach recently is to develop Fe- and Co-based nitrogen (N)-containing complexes supported on carbon materials through annealing method (Chen et al 2015; Fu et al. 2013; Ghanbarlou et al. 2015; Jiang et al. 2013; Peng et al. 2013; Wang et al. 2015; Wu et al. 2011; Xie et al. 2014).

In this paper, as the catalyst support, we chose graphene oxide (GO) as a starting material to dope with $\mathrm{N}$. The high surface area, excellent dispersity and the high range of oxygen functional groups of GO will efficiently allow nucleation, increase the oxides-type active sites for catalytic reaction and thus has high potential to be a good candidate to be used in various applications (Dreyer et al. 2014; Xie et al. 2014). Besides, the presence of other functional groups on GO such as carboxyl, carbonyl, lactone and etc. makes GO a good basis for the incorporation of the $\mathrm{N}$ into the carbon matrix and create metal-N-C sites efficiently (Li et al. 2009; Xie et al. 2014).

The fact that we chose $\mathrm{Fe}$ and $\mathrm{Co}$ is because of their electronegativity 1.88 and 1.83 , respectively, that is lower than carbon (2.55). It results in higher ability of $\mathrm{Fe}$ and $\mathrm{Co}$ to attract electron pair rather than $\mathrm{C}$ does thus forming metal ions and contributing to the enhanced electrocatalytic activity (Parvez et al. 2012). With the addition of $\mathrm{N}$ into the carbon matrix, $\mathrm{N}$ will provide an additional lone pairs of electrons that could facilitate the process of electron transfer from carbon to oxygen. This can improve and increase the electronic properties of the carbon materials that leads to enhanced ORR activity (Chen et al. 2010; Mabena et al. 2011). The addition of $\mathrm{N}$ into carbon network is capable to decompose reactive and poisonous intermediates such as $\mathrm{H}_{2} \mathrm{O}_{2}$ to $\mathrm{O}_{2}$ during the ORR (Maldonado \& Stevenson 2005). These modifications are believed to contribute some useful knowledge of developing an effective non-noble metal electrocatalyst.

Many methods were reported to produce FeCo supported nitrogen-doped carbon materials: (1) heat treatment of a mixture consisting of $\mathrm{Fe}$ and $\mathrm{Co}$ salts and $\mathrm{N}$ precursor (from salt or polymer) in an inert atmosphere followed by acidleaching (Fu et al. 2013; Xie et al. 2014); (2) heat treatment of a mixture consisting of $\mathrm{Fe}$ and Co salts and $\mathrm{N}$ precursor (from salt or polymer) in an inert atmosphere (without acidleaching) (Jiang \& Chu 2014; Ma et al. 2014); and (3) wet chemical reduction using reducing agent such as sodium borohydride $\left(\mathrm{NaBH}_{4}\right)$, hydrazine hydrate $\left(\mathrm{H}_{6} \mathrm{~N}_{2} \mathrm{O}\right)$, ethylene glycol $\left(\mathrm{C}_{2} \mathrm{H}_{6} \mathrm{O}_{2}\right)$, etc. (Bide et al. 2016; Ghanbarlou et al. 2015). Based on the previous studies, heat treatment or thermal annealing has been proven to be a cost-effective method for large-scale production of graphene-based electrocatalysts (Deng et al. 2011; Lin et al. 2013; Zhang et al. 2016).

In this work, we have prepared a low cost and potential non-noble metal electrocatalyst through thermal annealing method at varied high temperatures, of iron (III) chloride and cobalt (II) nitrate hexahydrate supported N-doped reduced GO with/without the presence of any surfactant under $\mathrm{N}_{2}$ atmosphere. The effect of high annealing temperatures and surfactant on the physical morphology of the FeCo-NG electrocatalyst are discussed in this paper.

\section{METHODOLOGY}

\section{SYNTHESIS OF GRAPHENE OXIDE (GO)}

Graphite powder $(3 \mathrm{~g})$ and $\mathrm{NaNO}_{3}(1.5 \mathrm{~g})$ was mixed in $100 \mathrm{~mL}$ of $\mathrm{H}_{2} \mathrm{SO}_{4}(98 \%)$ and kept under ice bath with continuous stirring. The mixture was stirred for $1 \mathrm{~h}$ at this temperature and potassium permanganate (12 g) was added to the suspension slowly in order to maintain the reaction temperature below $15^{\circ} \mathrm{C}$. The ice bath was removed and the mixture was stirred at room temperature until it became pasty brownish and kept under stirring for $24 \mathrm{~h}$. It was then diluted with the addition of $150 \mathrm{~mL}$ deionized water and stirred for $24 \mathrm{~h}$. Finally, the solution was treated with $15 \mathrm{~mL} \mathrm{H}_{2} \mathrm{O}_{2}$ to terminate the reaction by an appearance of yellow color. The mixture was stirred for another $2 \mathrm{~h}$. For purification purposes, the mixture was washed by rinsing and centrifugation with $5 \% \mathrm{HCl}$ and followed by deionized water 5 times. The graphite oxide slurry was then dried at room temperature in the vacuum oven for $24 \mathrm{~h}$. The graphite oxide powder was added with deionized water for the preparation of graphene oxide dispersion (Wang et al. 2013).

\section{SYNTHESIS OF FECO-NG}

$\mathrm{FeCl}_{3}$ and $\mathrm{Co}\left(\mathrm{NO}_{3}\right)_{2} \cdot 6 \mathrm{H}_{2} \mathrm{O}$ was dispersed in deionized water $(50 \mathrm{ml})$ and pretreated with ultrasonication for $1 \mathrm{~h}$. After the addition of dicyandiamide (DCDA), the mixture was stirred for another $2 \mathrm{~h}$. Subsequently, the aqueous solution of GO $(100 \mathrm{mg})$ was dispersed in DI water $(50 \mathrm{ml})$ after pretreated with ultrasonication for $1 \mathrm{~h}$. The aqueous solution of GO was added slowly into the above solution. After $24 \mathrm{~h}$ constant stirring at $80^{\circ} \mathrm{C}$, the resultant solution was dried in an oven and collected for annealing in an $\mathrm{N}_{2}$ stream at flow rate of $100 \mathrm{sccm}$ for $2 \mathrm{~h}$ to form FeCo-NG- $\mathrm{t}(\mathrm{t}$ is the annealing temperature, $650^{\circ} \mathrm{C}$ to $\left.850^{\circ} \mathrm{C}\right)(\mathrm{Chen}$ et al. 2015).

\section{PHYSICAL CHARACTERISATION}

The overall morphology of the FeCo-NG samples was obtained using scanning electron microscopy (SEM, ZEISS EVO MA 10) with an accelerating voltage of $10 \mathrm{kV}$ and the nanostructure of the materials and distribution of nanoparticles supported on NG were studied using transmission electron microscopy (TEM, CM 12 PHILIPS) operated at an accelerating voltage of $100 \mathrm{kV}$. For SEM characterisation, wet GO was incorporated on a conductive carbon substrate, a double side adhesive disk, used to support the sample on a flat specimen holder. The GO was vapor-deposited with a thin gold layer (coating purpose) before inserting in VP-mode. For TEM characterisation, the FeCo-NG was suspended in ethanol, and a drop of the 
suspension was placed on a copper grid, followed by solvent evaporation in a vacuum at room temperature.

RESULTS AND DISCUSSION

PHYSICAL CHARACTERIZATION

SEM and TEM Analysis

Fig. 1a and 1b show SEM images of typical graphite powder and GO. Fig. 1a shows that the sheets are closely stacked together, overlapping each other thus forming a very compact structure of graphite. Fig. 1b portrays the exfoliated graphene oxide. GO has theoretically larger surface area than graphite. The SEM image of GO displays a thinner curtain layer (sheets) compared to typical graphite. The obtained morphology of GO specifies the good exfoliation of graphite during the oxidation process (Sobon et al. 2012).
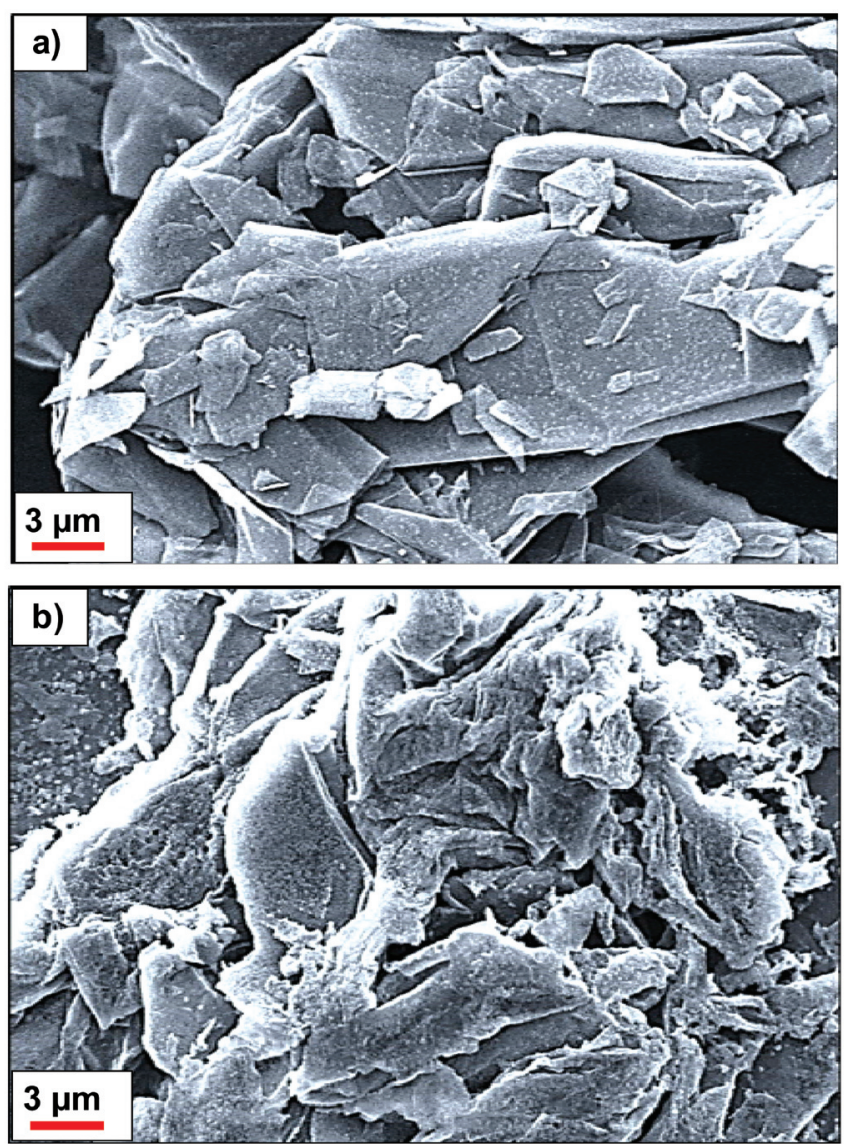

FIGURE 1. SEM images of (a) graphite and (b) GO at the magnification of $3,000 \mathrm{X}$

While TEM analyses (Fig. 2a and 2b) present the quantitative measures of the nanomaterials surface morphology for typical graphite powder and GO, respectively. As can be seen in Fig. 2b, it reveals the transparent crumpledwrinkle multilayer agglomerate structure of GO. During the oxidation process, the presence of various defects and functional groups that carrying $\mathrm{sp}^{3}$ hybridized carbon atoms caused the appearance of the bends and wrinkles on GO nanosheets at several places to arise (Verma et al. 2011).
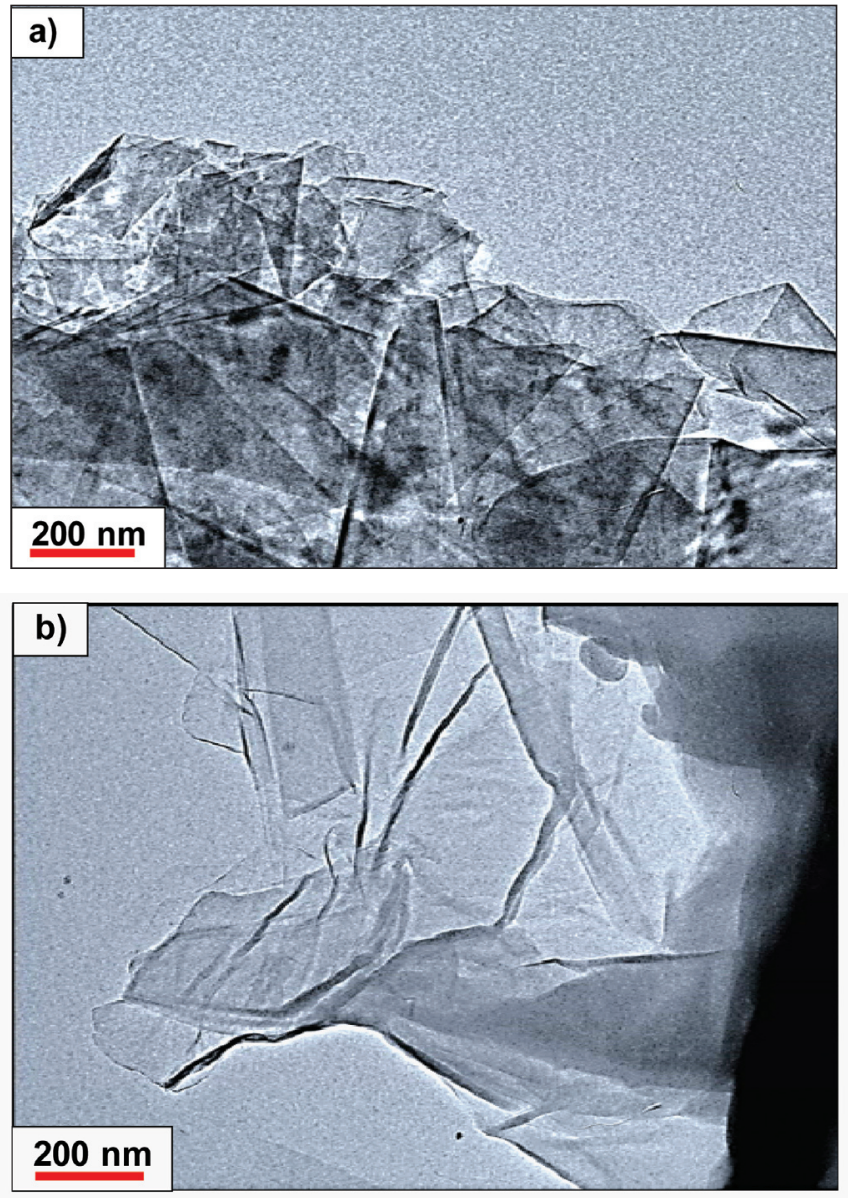

FIGURE 2. TEM images of (a) graphite and (b) GO, at the magnification of $13,000 \mathrm{X}$

It is well known that the annealing temperature is one of the important key factors on the catalytic activity of the nonnoble metal eletrocatalysts (Jaouen et al. 2006). However, there is little research on the effect of annealing temperatures towards the morphology of the non-noble catalysts. Fig. 3 (a, b, c, d and e) show the TEM images of electrocatalyst FeCo-NG that were synthesized at different annealing temperatures $\left(650^{\circ} \mathrm{C}-850^{\circ} \mathrm{C}\right)$. The average diameter of the FeCo nanoparticles for FeCo-NG-650, FeCo-NG-700, FeCo-NG-750, FeCo-NG-800 and FeCo-NG-850 is 247.8 $\pm 30.4 \mathrm{~nm}, 238.3 \pm 22.6 \mathrm{~nm}, 271.3 \pm 15.6 \mathrm{~nm}, 252.2 \pm 9.6$ $\mathrm{nm}$ and $491.3 \pm 29.7 \mathrm{~nm}$, respectively. The agglomerations of the particles were obviously shown. The spherical and larger crystalline particles of FeCo were unevenly distributed on the wrinkle reduced graphene oxide sheets surface. As the heat-treatment temperatures increase, the nanoparticles tend to increase in size and agglomeration tends to appear at certain spots. For FeCo-NG- $850^{\circ} \mathrm{C}$, loose network between the FeCo nanoparticles and the graphene support is observed in the image. These might be due to the weak electrostatic interactions between $\mathrm{Fe}, \mathrm{Co}, \mathrm{N}$ and GO and it is expected that the nanoparticles ( $\mathrm{Fe}$ and $\mathrm{Co}$ ) are not attracted onto the 
graphene sheets thus inhibit the reduction of FeCo and GO (Fan et al. 2015). The metal nanoparticles average size is one of the most important factors that has major contribution towards the excellent catalytic activity and durability of fuel cells (Lu \& Chen 2012; Wang et al. 2010; Zhang et al. 2007). The smaller the metal nanoparticles size, the interaction of metal atoms with carbon support is stronger compared to the larger metal nanoparticles that would increase the charge transfer, thus results in better catalytic activity (Park et al. 2007). The surface area to volume ratio of an electrocatalyst can be increased by decreasing the size of nanoparticles (Ibrahim et al. 2015). A few researchers have studied on the way the metal nanoparticles size affected the electrocatalytic performance (Lu \& Chen 2012; Wang et al. 2010; Zhang et al. 2007). Zhang et al. 2007 focused on how the increased of heat treatment could greatly influence the bimetal PdCo nanoparticles size. In the study, as the temperature increases from $300^{\circ} \mathrm{C}$ to $700^{\circ} \mathrm{C}$, the nanoparticles size of PdCo increases, from an average of $9 \mathrm{~nm}$ to $15 \mathrm{~nm}$, respectively, thus $\mathrm{PdCo}-$ 300 displayed the best ORR performance compared to PdCo700 (Zhang et al. 2007). Besides, the high temperature applied during the annealing process of the electrocatalyst would not only cause the larger nanoparticles size obtained, but also could give rise to the agglomeration of the metal particles (Wang et al. 2010; Zhang et al. 2007). Agglomeration of metal catalyst particles can lead to lower active surface area for the reaction to occur and lower electronic conductivity, thus results to poor electrocatalytic performance (Antolini 2014; Samad et al. 2018).

It is also believed that the intense agglomeration and the unevenly distributed particles are due to the absence of the surfactant. Fig. $3 \mathrm{f}$ depicts the TEM image of FeCo-NG$650 / \mathrm{EG}$ with the presence of ethylene glycol as a surfactant. It reveals the smaller FeCo nanoparticles size with an average diameter of about $50.4 \pm 7.2 \mathrm{~nm}$, with a better nanoparticles dispersion on the reduced GO support. It can be summarized that with the presence of surfactant such as ethylene glycol, it is able to act not only as a reducing agent but also as a dispersing agent, that will result in better dispersion and less agglomeration of the metal nanoparticles (Bide et al. 2016; Fashedemi \& Ozoemena 2013; Fernandez Alvarez 2011; Ghanbarlou et al. 2015; Zamanpour et al. 2012).
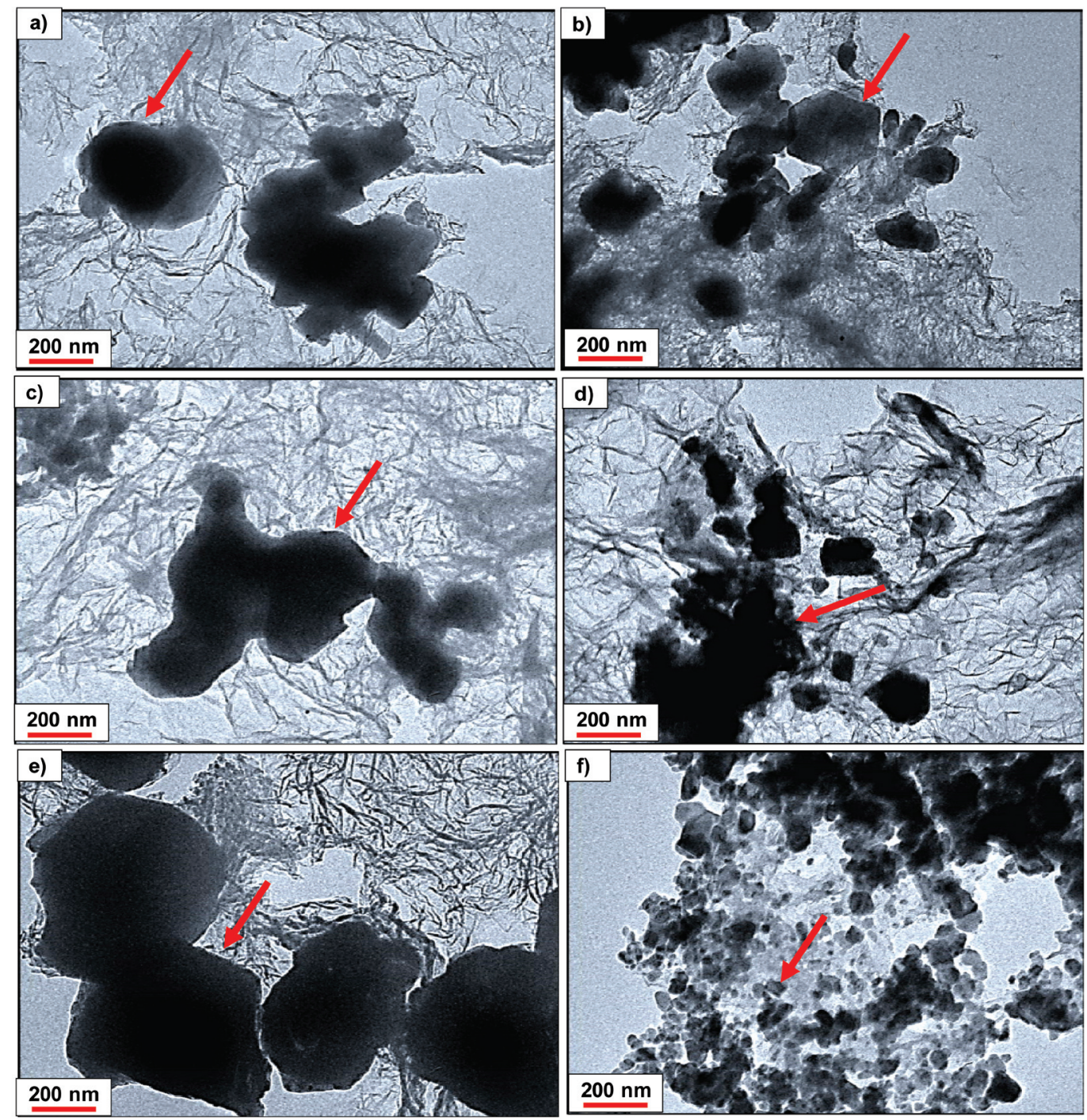

FIGURE 3. TEM images of (a) FeCo-NG-650, (b) FeCo-NG-700, (c) FeCo-NG-750, (d) FeCo-NG-800, (e) FeCo-NG-850 and (f) FeCoNG-650/EG, at the magnification of $17,000 \mathrm{X}$ 
CONCLUSION

The TEM analysis shows that the electrocatalyst FeCo-NG was successfully synthesized through thermal annealing method. However, the high annealing temperature and the absence of the surfactant caused the nanoparticles of FeCo to agglomerate with larger particles size and uneven distribution that will deteriorate the electrocatalytic activity. The addition of surfactant results in smaller average diameter size of FeCo nanoparticles with better dispersion on the reduced GO nanosheets. The smaller size of FeCo is expect to enhance the electrocatalytic activity of the catalyst.

\section{ACKNOWLEDGEMENT}

This work is financially supported by Universiti Kebangsaan Malaysia (UKM) through University Research Grant (DIP2014-002) and (DIP-2017-024).

\section{REFERENCES}

Alvarez, G. F., Mamlouk, M., Kumar, S. M. S. \& Scott, K. 2011. Preparation and characterisation of carbonsupported palladium nanoparticles for oxygen reduction in low temperature PEM fuel cells. Journal of Applied Electrochemistry 41: 925-937.

Antolini, E. 2014. Iridium as catalyst and cocatalyst for oxygen evolution/reduction in acidic polymer electrolyte membrane electrolyzers and fuel cells. ACS Catalysis 4(5): 1426-1440.

Bashyam, R. \& Zelenay, P. 2006. A class of non-precious metal composite catalysts for fuel cells. Nature 443(7107): 63-66.

Bide, Y., Nabid, M. R. \& Etemadi, B. 2016. Facile synthesis and catalytic application of selenium doped graphene/ $\mathrm{CoFe}_{2} \mathrm{O}_{4}$ for highly efficient and noble metal free dehydrogenation of formic acid. International Journal of Hydrogen Energy 41(44): 20147-20155.

Chen, M., Liu, J., Zhou, W., Lin, J. \& Shen, Z. 2015. Nitrogen-doped graphene-supported transition-metals carbide electrocatalysts for oxygen reduction reaction. Scientific Reports 5(10389): 1-10.

Chen, Z., Higgins, D. \& Chen, Z. 2010. Nitrogen doped carbon nanotubes and their impact on the oxygen reduction reaction in fuel cells. Carbon 48(11): $3057-$ 3065.

Deng, D., Pan, X., Yu, L., Cui, Y., Jiang, Y., Qi, J., Li, WX., Fu, Q., Ma, X. \& Xue, Q. 2011. Toward N-doped graphene via solvothermal synthesis. Chemistry of Materials 23(5): 1188-1193.

Dreyer, D. R., Todd, A. D. \& Bielawski, C. W. 2014. Harnessing the chemistry of graphene oxide. Chemical Society Reviews 43(15): 5288-5301.

Fan, X., Gao, H., Kou, X., Zhang, B. \& Wang, S. 2015. Synthesis of FeCo-reduced graphene oxide composite and its magnetic and adsorption properties. Materials Research Bulletin 65: 320-324.
Fashedemi, O. O. \& Ozoemena, K. I. 2013. Enhanced methanol oxidation and oxygen reduction reactions on palladium-decorated FeCo@Fe/C core-shell nanocatalysts in alkaline medium. Physical Chemistry Chemical Physics 15(48): 20982-20991.

Fu, X., Liu, Y., Cao, X., Jin, J., Liu, Q. \& Zhang, J. 2013. FeCo-Nx embedded graphene as high performance catalysts for oxygen reduction reaction. Applied Catalysis B: Environmental 130: 143-151.

Ghanbarlou, H., Rowshanzamir, S., Kazeminasab, B. \& Parnian, M. J. 2015. Non-precious metal nanoparticles supported on nitrogen-doped graphene as a promising catalyst for oxygen reduction reaction: synthesis, characterization and electrocatalytic performance. Journal of Power Sources 273: 981-989.

Gong, K., Du, F., Xia, Z., Durstock, M. \& Dai, L. 2009. Nitrogen-doped carbon nanotube arrays with high electrocatalytic activity for oxygen reduction. Science 323(5915): 760-764.

Ibrahim, R. M., Markom, M. \& Razak, K. F. A. 2015. Optical Properties of $\mathrm{Fe}^{2+}$ Ion Doped ZnS Nanoparticles Synthesized Using co-Precipitation Method. Jurnal Kejuruteraan 27: 87-94.

Jaouen, F., Lefèvre, M., Dodelet, J. P. \& Cai, M. 2006. Heat-treated $\mathrm{Fe} / \mathrm{N} / \mathrm{C}$ catalysts for $\mathrm{O} 2$ electroreduction: are active sites hosted in micropores? The Journal of Physical Chemistry B 110(11): 5553-5558.

Jiang, R. \& Chu, D. 2014. Comparative study of CoFeNx/C catalyst obtained by pyrolysis of hemin and cobalt porphyrin for catalytic oxygen reduction in alkaline and acidic electrolytes. Journal of Power Sources 245: 352-361.

Jiang, S., Zhu, C. \& Dong, S. 2013. Cobalt and nitrogencofunctionalized graphene as a durable non-precious metal catalyst with enhanced ORR activity. Journal of Materials Chemistry A 1(11): 3593-3599.

Kamaruddin, S. K., Daud, W. R. W., Som, A. M. \& Masdar, M. S. 2007. Conceptual design of $5 \mathrm{~kW}$ PEM fuel cell stack. Jurnal Kejuruteraan 19: 43-54.

Koutsopoulos, S., Barfod, R., Eriksen, K. M. \& Fehrmann, R. 2017. Synthesis and characterization of iron-cobalt (FeCo) alloy nanoparticles supported on carbon. Journal of Alloys and Compounds 725: 1210-1216.

Li, X., Wang, H., Robinson, J. T., Sanchez, H., Diankov, G. \& Dai, H. 2009. Simultaneous nitrogen doping and reduction of graphene oxide. Journal of the American Chemical Society 131(43): 15939-15944.

Lin, Z., Waller, G. H., Liu, Y., Liu, M. \& Wong, C. P. 2013. Simple preparation of nanoporous few-layer nitrogendoped graphene for use as an efficient electrocatalyst for oxygen reduction and oxygen evolution reactions. Carbon 53: 130-136.

Lu, Y. \& Chen, W. 2012. Size effect of silver nanoclusters on their catalytic activity for oxygen electro-reduction. Journal of Power Sources 197: 107-110.

Ma, L., Shen, X., Zhu, G., Ji, Z. \& Zhou, H. 2014. FeCo nanocrystals encapsulated in N-doped carbon 
nanospheres/thermal reduced graphene oxide hybrids: Facile synthesis, magnetic and catalytic properties. Carbon 77: 255-265.

Mabena, L. F., Ray, S. S., Mhlanga, S. D. \& Coville, N. J. 2011. Nitrogen-doped carbon nanotubes as a metal catalyst support. Applied Nanoscience 1(2): 67-77.

Maldonado, S. \& Stevenson, K. J. 2005. Influence of nitrogen doping on oxygen reduction electrocatalysis at carbon nanofiber electrodes. The Journal of Physical Chemistry B 109(10): 4707-4716.

Park, I. S., Park, K. W., Choi, J. H., Park, C. R. \& Sung, Y. E. 2007. Electrocatalytic enhancement of methanol oxidation by graphite nanofibers with a high loading of PtRu alloy nanoparticles. Carbon 45(1): 28-33.

Parvez, K., Yang, S., Hernandez, Y., Winter, A., Turchanin, A., Feng, X. \& Müllen, K. 2012. Nitrogen-doped graphene and its iron-based composite as efficient electrocatalysts for oxygen reduction reaction. ACS nano 6(11): 95419550.

Peng, H., Mo, Z., Liao, S., Liang, H., Yang, L., Luo, F., Song, H., Zhong, Y. \& Zhang, B. 2013. High performance Feand $\mathrm{N}$-doped carbon catalyst with graphene structure for oxygen reduction. Scientific Reports 3: 1765.

Samad, S., Loh, K. S., Wong, W. Y., Lee, T. K., Sunarso, J., Chong, S. T. \& Daud, W. R. W. 2018. Carbon and noncarbon support materials for platinum-based catalysts in fuel cells. International Journal of Hydrogen Energy 43: 7823-7854.

Sobon, G., Sotor, J., Jagiello, J., Kozinski, R., Zdrojek, M., Holdynski, M., Paletko, P., Boguslawski, J., Lipinska, L. \& Abramski, K. M. 2012. Graphene oxide vs. reduced graphene oxide as saturable absorbers for Er-doped passively mode-locked fiber laser. Optics Express 20(17): 19463-19473.

Verma, S., Mungse, H. P., Kumar, N., Choudhary, S., Jain, S. L., Sain, B. \& Khatri, O. P. 2011. Graphene oxide: an efficient and reusable carbocatalyst for aza-Michael addition of amines to activated alkenes. Chemical Communications 47(47): 12673-12675.

Wang, C., Wang, G., van der Vliet, D., Chang, K.-C., Markovic, N. M. \& Stamenkovic, V. R. 2010. Monodisperse $\mathrm{Pt}_{3} \mathrm{Co}$ nanoparticles as electrocatalyst: the effects of particle size and pretreatment on electrocatalytic reduction of oxygen. Physical Chemistry Chemical Physics 12(26): 6933-6939.

Wang, D., Yan, W., Vijapur, S. H. \& Botte, G. G. 2013. Electrochemically reduced graphene oxide-nickel nanocomposites for urea electrolysis. Electrochimica Acta 89: 732-736.
Wang, J., Wang, G., Miao, S., Li, J. \& Bao, X. 2015. Graphene supported iron based nanoparticles encapsulated in nitrogen-doped carbon as a synergistic catalyst for hydrogen evolution and oxygen reduction reactions. Faraday Discussions 176: 135-151.

Wu, G., Nelson, M., Ma, S., Meng, H., Cui, G. \& Shen, P. K. 2011. Synthesis of nitrogen-doped onion-like carbon and its use in carbon-based CoFe binary non-preciousmetal catalysts for oxygen-reduction. Carbon 49(12): 3972-3982.

Xie, Y., Li, H., Tang, C., Li, S., Li, J., Lv, Y., Wei, X. \& Song, Y. 2014. A high-performance electrocatalyst for oxygen reduction based on reduced graphene oxide modified with oxide nanoparticles, nitrogen dopants, and possible metal-NC sites. Journal of Materials Chemistry A 2(6): 1631-1635.

Zamanpour, M., Chen, Y., Hu, B., Carroll, K., Huba, Z. J., Carpenter, E., Lewis, L. H. \& Harris, V. G. 2012. Largescale synthesis of high moment FeCo nanoparticles using modified polyol synthesis. Journal of Applied Physics 111(7): 07B528.

Zhang, G., Lu, W., Cao, F., Xiao, Z. \& Zheng, X. 2016. Ndoped graphene coupled with Co nanoparticles as an efficient electrocatalyst for oxygen reduction in alkaline media. Journal of Power Sources 302: 114-125.

Zhang, L., Lee, K. \& Zhang, J. 2007. The effect of heat treatment on nanoparticle size and ORR activity for carbon-supported $\mathrm{Pd}-\mathrm{Co}$ alloy electrocatalysts. Electrochimica Acta 52(9): 3088-3094.

Zheng, Y., Jiao, Y., Jaroniec, M., Jin, Y. \& Qiao, S. Z. 2012. Nanostructured metal-free electrochemical catalysts for highly efficient oxygen reduction. Small 8(23): 3550-3566.

Shuaiba Samad, Yusra Nadzirah Yusoff, "Kee Shyuan Loh, Wai Yin Wong

Fuel Cell Institute,

Universiti Kebangsaan Malaysia, Malaysia.

${ }^{*}$ Corresponding author;

email: ksloh@ukm.edu.my

Received date: $10^{\text {th }}$ July 2018

Accepted date: $13^{\text {th }}$ September 2018

Online first date: $1^{\text {st }}$ October 2018

Published date: $30^{\text {th }}$ November 2018 